\title{
Adolescent Reproductive Health in Indonesia: Contested Values and Policy Inaction
}

\author{
Iwu Dwisetyani Utomo and Peter McDonald
}

\begin{abstract}
This study examines the changing social and political context of adolescent sexual and reproductive health policy in Indonesia. We describe how, in 2001, Indonesia was on the brink of implementing an adolescent reproductive health policy that was consistent with international agreements to which the Indonesian government was a party. Although the health of young Indonesians was known to be at risk, the opportunity for reform passed quickly with the emergence of a new competing force, Middle Eastern fundamentalist Islam. Faced with the risk of regional separatism and competing politico-religious influences, the Indonesian government retreated to the safety of inaction in this area of policy. In the absence of a supportive and committed political environment that reinforces policy specifically targeted to young people's reproductive health, extremist approaches that involve considerable health risk prevailed. The sexual and reproductive values and behaviors that are emerging among single young people in contemporary Indonesia are conditioned by a political context that allows the conflicting forces of traditional Indonesian values, Westernization, and the strong emerging force of fundamentalist Islam to compete for the allegiance of young people. (STUDIES in Family PlanNing 2009; 40[2]: 133-146)
\end{abstract}

Indonesia is comprised of numerous divergent regional cultures. From the beginnings of the nationalist movement in the 1920s, the leaders recognized the need to foster a sense of nationhood among young Indonesians, lest the country's political identity disintegrate. As expressed by its national motto, "Unity in diversity," Indonesia sought to implement what later became known in the policy contexts of Canada and Australia and then elsewhere as multiculturalism: tolerance of differences in religion and culture within a national political and legal framework. Multiculturalism was codified in the Pancasila, the five principles of the Indonesian government.

Eighty years after the emergence of Indonesian nationalism, this multiculturalism can be described as "idealized morality" (McDonald 1994), which takes the form of respect for parents and elders, respect for nationhood, religious tolerance, and social justice. It also incorporates a form of Islam that is syncretic (accommodating disparate beliefs) rather than fundamentalist. For young people living by this code, engaging in sex before marriage brought great shame upon them and their families, but such behavior was accepted as a human failing. Young

Iwu Dwisetyani Utomo is a Fellow and Peter McDonald is Professor and Director, Australian Demographic and Social Research Institute, The Australian National University, ACT, Canberra 0200.E-mail:iwu.utomo@anu.edu.au. people discovered to be having sex before marriage may have been ostracized by their families, but severe legal punishment (as specified by syariah law) was not applied. Accordingly, in order to avoid shame as a consequence of human frailty, young people were married off at a very young age in unions arranged by their parents. This idealized morality was challenged, initially, by liberal Western ideas, and an opportunity for policy change addressing adolescents' reproductive health arose around 2001. In recent years, this opportunity has receded in the wake of the spread of Middle Eastern Islamic fundamentalist ideas.

This study examines the changing social and political context of adolescent sexual and reproductive health policy in the Republic of Indonesia. The study seeks to provide an interpretation of the extant literature and political developments within the theoretical framework of Indonesian idealized morality as it exists in contrast with Western and Middle Eastern ideas. The study also reviews research on the incidence of adolescent sexual behavior in Indonesia.

\section{Young Indonesians' Changing Political and Moral Environment}

In the past two decades, the social environment of young people $^{1}$ in Indonesia has changed rapidly from that ex- 
perienced by their parents at the same age. A generation ago, even in Jakarta (the capital), the behavior of young people was highly constrained. Marriages were generally arranged by parents (Hull 1975; Sudewa 1980; Soeradji and Hatmadji 1982; McDonald 1984; Singarimbun 1987; Jones 1994), and young people were not free to mix with members of the opposite sex except at closely supervised events (Arian 1982; Muliakusuma 1982). Women married very early, and their educational attainment rarely exceeded the secondary-school level. Peer pressure was not strong, especially for young women, because "once they reached puberty, women were not merely kept isolated from men, they were also- and more devastatingly-kept sequestered from each other" (Tiwon 1996: 50-51). What youth culture existed was related to the achievement of political independence and economic development - that is, to group ideals rather than to personal ones.

With the influence of Western ideas, the traditional orientation changed, and a new emphasis was placed on education, which led to much later age at marriage (Geertz 1961; Iskandar 1970; Soeradji 1979; Soeradji and Hatmadji 1982; Hull 2002; Jones 2002), especially for women; freedom to choose one's own marriage partner (Malhotra 1991; McDonald 1995; Grace 1996; Hull 2002; Jones 2002); and greater freedom for young single people to socialize with members of the opposite sex and develop romantic relationships. This increase in personal freedom and access to education has enabled young women to define themselves in terms of their career aspirations as well as their roles within their families. Figure 1 compares the proportions of women attending school with those who were married across three decades. The points at which the two lines intersect (where the proportion in school equals the proportion married) has shifted upward continuously from age 16 in 1971, to 17 in 1980, to 18 in 1990, and to 19 in 1997; it is still rising.

By the mid-1990s, young Indonesians were exposed to a number of conflicting moral values. On the one hand, liberal values were promoted through Westernized education, media marketing propaganda, and peer pressure; on the other hand, traditional Indonesian Islamic teaching and moral values were promoted by religious schools and groups, families (especially those of the older generation), and the state. Signs of a potential détente between the forces of Westernization and traditionalism were emerging. Young Indonesians were developing values influenced by the West but with strong traditional Indonesian Islamic modifications, so that the opportunity arose to create effective reproductive health and sex-education programs and services that would not be offensive to those of various religions, ethnicities, or the Indonesian state.
Figure 1 Percentage of women aged 15-24 who are attending school and percentage who are married, Indonesia, 1971-1997
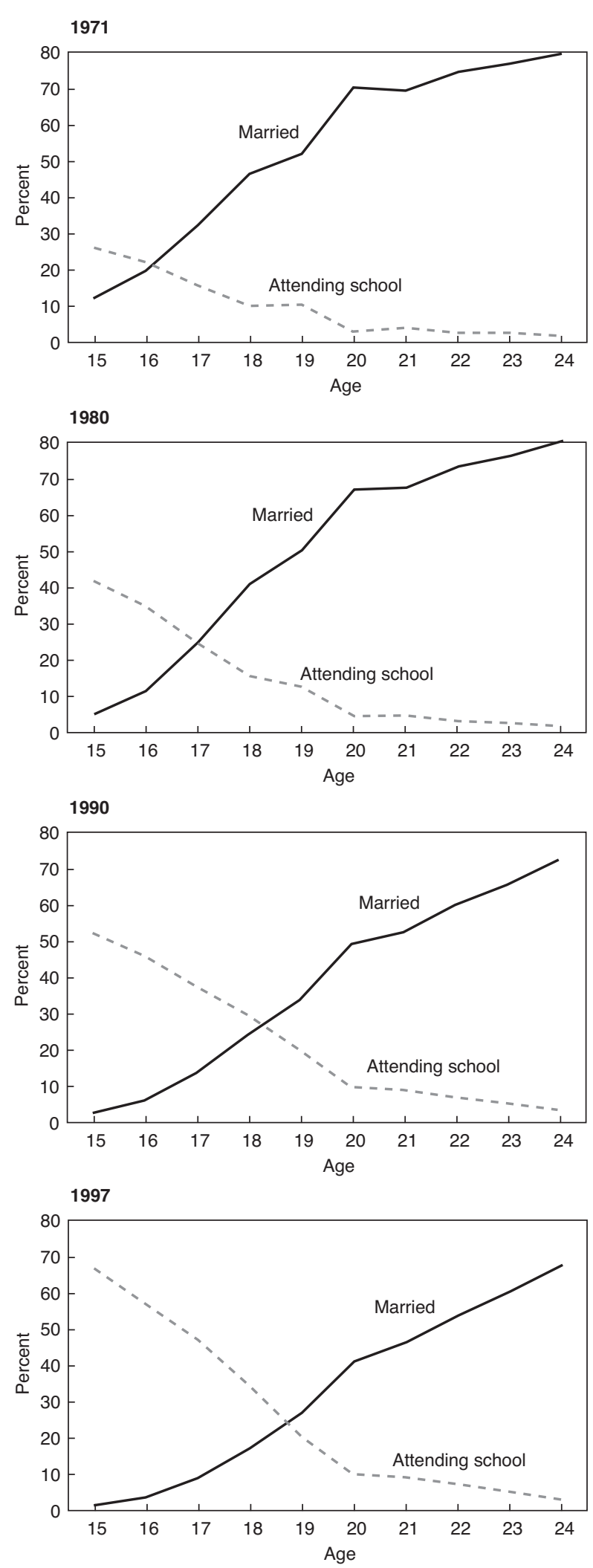

Source: Kurniawan 2000, Figure 3, page 15, calculated from the 1971, 1980, and 1990 Indonesian Population Census and the 1997 Indonesian National Social and Economic Survey. Jakarta: Central Bureau of Statistics. 
Toward the end of the 1990s, a more democratic environment evolved after the fall of Suharto, and simultaneously, the influence of Islamic fundamentalism on young people's moral values increased. Islamic youth groups were formed, and the number of young women wearing Muslim attire rose sharply. To maintain group solidarity among young people attached to these new religious groups, marriages are often arranged between members of the group. Members advocate conservative religious doctrine and actively promote the application of strict syariah law. Such groups are also often involved in anti-Western demonstrations. Nevertheless, conservative Islamic attire is often mixed with tight bluejeans, tight long-sleeved T-shirts, and matching jewelry, shoes, and handbags.

A behavioral continuum extends from extreme fundamentalism to casual Western style in clothing and activities. Many young women smoke and walk intimately with their partners. Punk and rock music are inseparable from the youth culture and share popularity with traditional ethnic and Islamic popular music. Night-time entertainment and venues offering sexual services are flourishing. Increasing numbers of young people use narcotics and engage in risky sexual activity. Modern clinics and religious boarding schools (pesantren) both provide rehabilitation services for drug users - services that were not readily available a decade ago. In the past decade, too, schools and universities that operate like Western schools have arisen in the big cities of Indonesia. Some even use English as the medium of instruction and employ foreign teachers (Gatra 1996). In contrast with Western-style schools, exclusive Islamic schools have been established, with annual enrollment fees as high as US\$10,000. A number of agencies now specialize in placing students in schools abroad. They organize placement, accommodation, host families, English courses, and entry tests. Advertisements for such services appear in newspapers and magazines such as Kompas, Republika, Femina, and Gatra. Of course, regional variation exists in the arena of these contested values; the contrasts are more prominent in the large cities, especially in Jakarta.

The conventional, older contest between Western modernization and Indonesian traditionalism has largely faded into the background. Indonesian traditionalism (idealized morality), the force that held the nation together and that dominated the political scene in the past, now contends with attacks from both sides: from the liberal Western perspective and from modern fundamentalist Islam. The emergence of Christian fundamentalism, a new influence from the West, has complicated the picture further. Whereas an enlightened reproductive health policy for young people was a possibility a decade ago, the Indonesian government has retreated once more to the safer ground of inactivity.

Policy inaction in relation to sexual and reproductive health for young people is a manifestation of a wider political debate in Indonesia. In what previously was a country with highly centralized governance, the power to legislate personal, moral issues has been extended to regional governments as a palliative to regional separatist movements, producing diverse approaches to sexual and reproductive health services for the young across the country. At the same time, a wide array of risky sexual behaviors are occurring every day in different parts of Indonesia, with the health of young Indonesians hanging in the balance.

Conflict surrounding sexuality and its expression came to a head in Indonesia through public discussion of the Rancangan Undang-Undang Anti-Pornografi dan Porno$a k s i$, the draft law against pornography and pornographic actions. When it was first proposed in 2005, this draft law was intended to restrict exposure to explicit sexual material to adults. In the first draft, however, the law extended well beyond this limited goal and sought to ban pornoaksi (pornographic actions), a newly created offense that could be interpreted as including wearing short skirts, showing one's navel, kissing in public, or dancing in a way that could be construed as erotic. Penalties attached to these offenses could be as great as five to ten years' imprisonment (Kompas 2006a). The draft bill was backed by fundamentalist Islamic groups that held huge organized demonstrations of support in the streets of Jakarta. The bill was attacked by feminist groups as imposing undue restrictions upon women and upon the way they dress. These groups pointed out that the law would be open to local interpretation, making women vulnerable to arrest in one region for wearing what would be considered normal attire in another.

The bill was also portrayed in regions with non-Islamic majorities such as Bali, North Sumatra, and East Nusa Tenggara as a shift toward the introduction of syariah law across Indonesia. The bill thus promoted regional secession movements in regions where Muslims were the minority. Previously, secession movements had erupted in strongly Islamic regions, such as Aceh. In this context of fear of national disintegration, the bill stalled and took on two forms: the controversial broad statement of reform and a much narrower version that focused on restricting children's exposure to explicit material. In the midst of this debate, the first issue of the Indonesian version of Playboy magazine was published, triggering demonstrations and attacks against the publisher. The office of the publisher has since moved from Jakarta to Denpasar in Bali. The Pornography Law was enacted in the broader form in October 2008, representing a victory for conservatives. 
The non-Islamic regions' fears concerning a subtle and slow shift to syariah law have also been fueled by the emergence, since 2001, of regional syariah laws in Aceh, Benkulu, South Sulawesi, West Java, West Nusa Tengga$\mathrm{ra}$, and West Sumatra. Fifty-four district regulations now implement syariah law requiring women to wear Muslim apparel, specifically the headscarf for workers and students, and restricting women's freedom of movement, requiring them to be accompanied by a closely related male when going out in public. The regulations impose afterhours movement restrictions for women and ban prostitution, adultery, drinking, and gambling (Utomo 2006a).

\section{Idealized Morality, the State, and Westernization}

A conceptual framework linking idealized morality, the state, and Westernization can be employed to explain how young Indonesians have developed new values concerning relationships between the sexes. Idealized morality, defined as the normative moral code that has developed over time within a society (McDonald 1994), includes traditional values, norms, and religious teachings. New values coming from the Western world or those developed through the modernization process often run counter to the idealized morality. The extent to which the new values are accepted or accommodated depends upon the extent to which the idealized morality is supported by the formal institutions of the society and the state.

In Indonesia, the relationship between state and religious institutions has been an uneasy one of struggle to form an alliance in support of traditional values that are seen as holding the state together. Young people, those aged 15-24, constitute 20 percent of the total population (CBS 2003). The state recognizes that change is often in the state's own interest and does not always stand in its way; indeed, the state sometimes promotes social change. An example is the shift in attitudes toward arranged marriage. In the past, Indonesian families married their daughters off when they were as young as nine or ten (Geertz 1961; McDonald and Abdurachman 1974) to save the parents the embarrassment of having an old maid in the family or, worse, an out-of-wedlock pregnancy. Religious and state organizations acted in concert with parents to enforce this custom. Currently, arranged marriages are uncommon except among fundamentalist Islamic groups, and parents encourage their daughters as well as their sons to continue their education and develop a career. In order to promote economic development, the state has an interest in advancing education and, hence, the marriage law has been changed accordingly.
During the period called the New Order (1968-98), the interplay of idealized morality and Westernization led young Indonesians to develop a specific national identity and ideology that became their frame of reference beyond their communities, families, and ethnicities (McDonald 1984). This frame of reference was shaped by the influences of the nation-state, education, media exposure, and Western influence, and served to legitimate new behaviors. For many young Indonesians, the values conveyed by these institutions provided alternatives to the values of and decisions made by their parents. As a result, the younger generation gained greater control over their own lives and were able to make more independent decisions concerning relationships prior to marriage, partner selection, and sexuality. Marriages based on romantic love became common, and the freedom to interact with the opposite sex prior to marriage increased. Relative to the old notions of idealized morality, the majority of young Indonesians based their attitudes and behaviors toward the opposite sex on the liberal end of the continuum.

This interpretation of change in the lives of young people in Indonesia, which applies to the reality of a decade ago, is currently complicated by the recent emergence of fundamentalist Islamic youth groups and culture. The state must now contend with two divergent movements for change: the diffuse but ubiquitous intervention of Western liberal ideas and the less widespread but more organized thrust of fundamentalist Islam. Both forces seek to gain favor with those adhering to traditional Indonesian Islamic values. Almost inevitably, the emergence of Islamic fundamentalism has slowed development of a state policy to safeguard reproductive health for young people and returned the government to a position of inaction.

\section{Young People and Sexuality}

\section{Sexual Information and Imagery and Sexual Permissiveness}

In the area of sexuality, young people in Indonesia face a confusing situation. On the one hand, their knowledge of the nature of sexuality and of safe sexual activity is limited because sex education is not provided by schools, except in a few cases where the approach to the subject is scientific or technical. Indonesian parents rarely educate their children concerning sex (Parini and Mudjajadi 1995; Utomo 2003a). Most parents of the current generation received no sex education from their own parents, nor were they free to mix with members of the opposite sex before marriage. Their own lack of experience makes it difficult, 
therefore, for them to provide information to their children. Discussion of sexuality is also difficult in formal or public settings for the reasons outlined above. Consequently, the topic of sexuality remains marginal in the health and education agendas. Access to contraception is highly restricted for single people. ${ }^{2}$ Human-relations education is almost unknown in Indonesia, rendering young people with little capacity to deal with the emotional and personal dimensions of relationships.

On the other hand, many young people come into daily contact with the stimulus of sexually explicit material through the entertainment and print media, on the Internet, and through their peers (see section on focusgroup discussions in Utomo 1997). Premarital sexual activity is taken for granted in the media, but the material, because of its market orientation, is designed to stimulate and to titillate rather than to educate. At the same time, the opportunities for young people to engage in sexual activity have increased. With the rise in prevalence of sexually transmitted diseases, especially HIV / AIDS (Djaelani 1995; Gunawan 1995; Yatim 1995), Indonesia is facing a potentially major public health problem (Utomo 1995). Furthermore, young people increasingly face the risk of premarital pregnancy, early marriage, and the physical, social, and economic disadvantages related to early childbearing (McDevitt et al. 1996). Marriages undertaken as a consequence of pregnancy carry a high risk of subsequent divorce. The media stimulates the young to think about recreational sex, but do not provide information that would enable young people to engage in sexual activity safely (Rajab 2006).

Increasing sexual permissiveness among the young in Indonesia has been clearly documented (Sadli and Affandi 1976; Sarwono 1981a and 1981b; Muninjaya 1993; Situmorang 2001; Utomo 2003b) and is also indicated by studies of premarital abortion and attempted abortion (Putra et al. 1984-85; Hull et al. 1993; Widyantoro 1992 and 1996; The Straits Times 2000). What appears in the media is another indicator of a society's sexual permissiveness. More than a decade ago, when the first author was collecting data for the 1994-95 Jakarta Sexuality and Marriage Values Survey, the media did not portray sexuality as liberally as they do today. Currently, television programs abound that deliver images and messages describing sexually permissive behavior. Only one national television channel (TVRI) exists, whereas more than 13 private channels are in operation. Middle- and upper-class families commonly have cable television, granting them access to national and international channels. One of the most popular programs on Indonesian television, delivered in various forms on all private channels, sometimes more than three times a day, is "Infotainment" — a gossip pro- gram about Indonesian celebrities. The program covers their relationships, wedding plans, marriages, newborns, breakups, and divorces. A decade ago, this type of program would not have passed the national media censoring committee, but because young people now represent such a large segment of the Indonesian market, programs designed for them have multiplied over the past decade. In the ostensible interest of balance, television channels also present fundamentalist Islamic soap operas.

Media offerings, place of residence, and the diversity of ethnic groups in Indonesia can all be linked to sexual permissiveness. Singarimbun's study (1991) among young people in Bali and Yogyakarta observed that they were more stimulated by the sexual sensations provided by the entertainment industries and mass media than young people were a generation ago. He found that sexual permissiveness was on the rise. Male respondents were more permissive than female respondents, and young people in urban environments were more permissive than rural young people. Differences in permissiveness among ethnic groups were also apparent: Balinese respondents were more tolerant of sexual behavior among the young than Javanese respondents, and rural Balinese were more permissive than urban Yogyakarta respondents. Using data for Yogyakarta from the 1994 Demographic Health Survey, Hanum (1996) indirectly estimated the incidence of premarital sex. The study concluded that greater permissiveness was found among respondents with higher levels of education, among those who had resided in an urban area before they were 12 years old, among those aged 17-21, and among those who worked in factories or sales and services or who had husbands working in factories or in the informal sector.

Historically, permissiveness toward sexual behavior was evident in Indonesia, especially among the Javanese, but after the coming of Islam in the fifteenth century, sexual attitudes, values, and behavior were increasingly controlled and guided by Islamic teaching. Those living in provinces where Muslims are a minority (Bali, East Nusa Tenggara, and North Sulawesi) appear to hold more permissive attitudes concerning sex than those living elsewhere (Utomo 1997). Sexual permissiveness is not restricted to young people who are still single but is also found among older married couples. An HIV / AIDS behavioral surveillance study by Utomo and his colleagues (1997) conducted in Manado, North Jakarta, and Surabaya indicated that most clients of female prostitutes regarded extramarital sex as normal or acceptable when they were away from their wives.

Visiting a prostitute has become a custom among young men in some areas. The practice of visiting prostitutes, particularly among male high-school and university 
students, has been documented in several studies (Sarwono 1981a and 1981b; Private Agencies Collaborating Together 1994; Utomo et al. 1997a). A study by Linnan et al. (1995) among 4,219 young people in East Java covering urban, periurban, and rural areas found that 7 percent of male respondents had had sex with prostitutes. The study found that having more than one sex partner was relatively common among males and females: 16 percent of urban males, 7 percent of urban females, 14 percent of periurban males, 3 percent of periurban females, 4 percent of rural males, and less than 1 percent of rural females reported having had more than one sex partner.

Utomo and his colleagues (1997b) reviewed numerous surveys and qualitative assessments of knowledge, attitudes, and behavior concerning HIV / AIDS among high-risk groups, including students, truck drivers, factory workers, sailors and seaport laborers, female and male prostitutes, female massage-parlor workers, clients of female prostitutes, homosexuals, and transvestites. They found that, on average, 37 to 68 percent of respondents had had multiple sex partners and (among male respondents) had had sex with female prostitutes more than once per month. A study by Ford et al. (1992) of 20 male homosexual prostitutes in Bali found that two had had female clients. Therefore, some male prostitutes have clients of both sexes. A study conducted in Bali by Jennaway (2008) indicates that before the economic and political crises and the bombing of Bali in 2005, the number of men working as gigolos increased to meet the demands of Western women.

The AIDS activist Baby Jim Aditya states that the term $M L$ (making love-with anyone) is often used by young people. Many young people say that they started $M L$ when they were in year seven at school. Boys who have had sex with commercial sex workers say that they did so because the girls of their age like to go out with older university students (Kompas 2006b). Earlier studies revealed that some boys preferred to have sex with commercial sex workers because they value the virginity of their girlfriends (Utomo 1997; Situmorang 2001). Although these studies were conducted among specific groups in the population and cannot be generalized, clearly sexual permissiveness is increasingly prevalent among young Indonesians.

Another indication of the rise in sexual permissiveness in Indonesia is the expansion of sex industries in urban and rural areas. Prostitutes of all classes operate officially as registered sex workers or function clandestinely in brothel complexes, hotels, nightclubs, discotheques, bars, massage parlors, barber shops, beauty parlors, escort services, streets, and markets (Hull et al. 1997; Van Der Sterren et al. 1997). From field observations made in April 2006, Utomo identified 152 places and contacts where sexual services are provided in Jakarta. Taxi drivers have come to use the phrase "lunch time-sex time" because they drive their customers, some of them wearing the uniforms of government employees, to short-stay hotels during lunch time. Twenty short-stay hotels in Jakarta have been documented that charge by the hour. Their prices range from Rp.80,000 to Rp.360,000 per hour (approximately US\$7-33 in 2009). Although estimating the number of prostitutes in Indonesia and the income generated from sex industries is difficult, Hull and his colleagues (1997: Table 4: 152) estimated that in 1994-95, 140,000 to 230,000 prostitutes were operating in Indonesia. Income generated from sex industries in 1994-95 were estimated to be Rp.7.2 trillion, increasing to Rp.18.2 trillion in 1996-97 (Sinar 1997). ${ }^{3}$

Sex stores have opened in and around the cities, but most customers remain reserved: they call the store and inquire about a certain object that they want and send their driver to pick it up (Tiara 1994). Treatment to make the vagina fragrant, tight, and dry is provided by salons, spas, traditional healers, and medical practitioners in the big cities of Indonesia. Medical clinics offer "virginity restoration" operations and cosmetic vaginal surgery (Utomo 2006a; Utomo and Hull 2006). The increasing number of places providing vaginal surgery and treatments are another indicator that urban Indonesian society has become increasingly permissive and sexualized.

\section{Premarital Sex}

No reliable data are available concerning the incidence of premarital sex in Indonesia as a whole. Only one national, government-initiated study, the 2003 Indonesia Young Adult Reproductive Health Survey, collected data on premarital sex and people's attitudes toward abortion (CBS and ORC Macro 2004). This survey found the incidence of premarital sex to be 1 percent among girls and 5 percent among boys. Based on the 2007 Indonesian Demographic and Health Survey, the incidence for premarital sex increased slightly to 1.3 percent among girls and 6.4 percent among boys. On the basis of the much higher levels observed in a number of smaller, more intensive research projects, we are convinced that these national measures are gross underestimates. Evidently, national surveys have not yet developed adequate methods for obtaining accurate reporting of this behavior.

The highest incidence of premarital sex among young people was reported by Purdy (2006) in a recent nonrepresentative study covering the four largest cities in Indonesia. The study revealed that 51 percent of the respondents had had premarital sexual intercourse. Consistent with Purdy's results, Situmorang's (2001) study conducted in Medan found that almost half of young men aged 21-24, more than one-fourth of those aged 18-20, and 12 
percent of those aged 15-17 had had premarital sex. A similar pattern applied to young women, although the proportions were much lower than those for men. In 1994, Hawari found that 31 percent of young people in Bogor, 27 percent in Sukabumi, and 22 percent in Bandung (all large urban areas of West Java) had had premarital sex (quoted in Hasmi 2001). These results are higher than Puspitawati's finding (Kompas 2006b) that 10 percent of college students in Bogor had ever had premarital sex.

A study in Yogyakarta (cited in Hasmi 2001) revealed that 29 percent of newlyweds had engaged in premarital sex. Another study (Purwanto and Harmudya 1992) found that 27 percent of young people in Bengkulu and 26 percent in Manado had had premarital sex (State Ministry of Population 1991). In all of these studies, boys were much more likely than girls to have engaged in premarital sex, and the difference was statistically significant. In Manado, for example, only 12 percent of girls said that they had experienced premarital sex, compared with 40 percent of boys.

A study by Utomo and his colleagues (2000) of 406 injecting drugs users (364 males and 43 females of whom 6.2 percent had ever married) in Jakarta revealed that 54 percent of male and 67 percent of female respondents had ever had sexual intercourse. Having had multiple sex partners was the norm among this group. Safe sex was rarely practiced, and condom use within the past month was very low.

\section{HIV Risk}

The spread of HIV and AIDS is becoming a major threat in Indonesia. Cases of the infection have been reported in all of the country's 33 provinces. Even in a conservative province such as West Sumatra, where Islamic practice is strong and widespread, $120 \mathrm{HIV}$ and AIDS cases have been recorded (Media Indonesia 2006b). In Papua, HIV cases have been documented among the general population, including government officials and religious leaders, and in Biak, 51 housewives are known to have been infected with the virus (Cendrawasih Pos 2006). By November 2008, HIV prevalence in Papua was 2.9 percent among adult men and 1.9 percent among adult women. It was higher in rural compared with urban areas (Janssen 2008). Recently, the government revealed that pregnant women infected with HIV have been found to exist in every district in Central Java.

Of the reported AIDS cases (635) in Indonesia in 2001, 146 (23 percent) were acquired by those aged 15-24. The main modes of transmission were through heterosexual intercourse (55 percent) and injecting drug use (19 percent) (UNAIDS 2002). By 31 December 2003, the cumulative number of AIDS cases and deaths were 1,371 and 479, respectively. Infection in 48 percent of these cases was ac- quired by heterosexual transmission and in 34 percent by injecting drug use (UNAIDS 2006). The incidence of injecting drug use among young Indonesians is increasing. A study conducted among injecting drug users in Jakarta in their early teens to age $29(\mathrm{~N}=406)$ revealed that 66 percent of the respondents had had sex in the past 12 months and that, on average, they had had unprotected sex with more than one sexual partner (Utomo et al. 2001).

\section{Premarital Pregnancy and Induced Abortion}

According to a 1989 estimate, 750,000 to one million induced abortions were performed per year in Indonesia (a ratio of 17-22 abortions per 100 live births) (Hull et al. 1993). A recent study conducted by the Indonesian Society of Obstetrics and Gynecology (POGI), the World Health Organization, and the Indonesian Ministry of Health revealed that an estimated 2.3 million abortions are performed each year in Indonesia. Of these, 600,000 cases were reported as resulting from unwanted pregnancies due to contraceptive failure, 700,000 cases were attributed to poor economic conditions, and one million were miscarriages (The Straits Times 2000). The Indonesia Planned Parenthood Association for Central Java has stated that many abortions in Indonesia are conducted under unsafe conditions (Media Indonesia 2006c).

A few studies conducted since 1970 have focused on premarital pregnancy and induced abortion. Most of the data for these studies were collected at clinics from patients seeking menstrual regulation, and the number of premarital abortions recorded is small. In a more systematic approach, Utomo and his colleagues (2001) conducted a comprehensive social mapping of abortion-service delivery points to estimate the incidence of abortion for the Indonesian population. The community-based survey covered eight provinces: six in Outer-Java (Bali, Java, Kalimantan, North and South Sulawesi, and Sumatra), and two in Eastern Indonesia (Eastern and West Nusa Tenggara). From these provinces, ten cities and six districts were selected. The study presented a national estimated incidence of two million abortions per year-a ratio of 43 abortions to 100 live births, or 30 percent of pregnancies. The study revealed that most women who had had an abortion were aged 20 or older (92 percent). One-third of the procedures were for single women. Among these respondents, the proportion who had undergone an induced abortion was higher at the district level (60 percent) than in the city (30 percent). Regardless of their marital status, one-third of the clients in the cities and half in the districts who had had an abortion were experiencing their first pregnancy. Of these, the majority were still single.

Indonesian law pertaining to induced abortion is not clear (Muhaimin et al. 1993); as a consequence, control- 
ling unsafe, potentially lethal practices and improving access to safe abortion are difficult. Induced abortion can be considered illegal under the following laws: Law No. 23/1992 on Health, Clause 76 of Law No. 29/1974 on Medical Practices, and Clause 348 of the Criminal Code (KUHP) (Media Indonesia Online 2006c). A bill that would incorporate regulations on safe abortion (Amendment to Law No. 23/1992) is still under discussion. Conservative attitudes toward abortion and premarital pregnancy were evident in the responses to the 1994-95 Jakarta Marriage Values and Sexuality Survey. The majority of respondents in the survey believed that a girl should continue her premarital pregnancy even when the father did not want to marry her (see Table 1). A more recent study by Situmorang (2001: Table 6.2) found that among single young people residing in Medan, female respondents (49 percent) were more likely than male respondents (44 percent) to tolerate premarital abortion.

The 1995 Indonesia Household Health Survey found that 11 percent of maternal deaths were due to complications following abortion (Widyantoro and Lestari 2004: 6). Although the study did not specifically mention unsafe abortion among single women, presumably a higher proportion of maternal deaths among single than married women are caused by unsafe abortion. The various means that women use to terminate an unwanted pregnancy by themselves include taking overdoses of Cytotec ${ }^{\circledR}$ tablets (a stomach-ulcer medication), using methods provided by traditional healers (especially forced stomach massage), and taking various traditional herbal mixtures (jamu) for menstrual regulation.

As Table 1 shows, the 1994-95 Jakarta Marriage Values and Sexuality Survey found that respondents aged 20-24 were more likely than younger respondents (aged 15-19) to report having friends who had experienced a premarital pregnancy (68 percent versus 23 percent). A lower incidence of premarital pregnancy was reported for relatives of the respondents, and almost no premarital abortions were reported among relatives of the respondents. Premarital pregnancy and premarital abortion tend to be kept secret among relatives. Also, the size of the population of respondents' friends is likely to be larger than the population of their relatives.

\section{Problems with Current Sexual and Reproductive Health Education and Policies}

In Indonesia, a married 16-year-old girl can have sex, become pregnant, and have access to reproductive health services and be considered a responsible adult and mother-to-be. In contrast, consistent with traditional idealized morality, a 17-year-old (of legal voting age) who is single and pregnant is considered a sinner and is disrespected. She is likely to be expelled from school, stigmatized, and isolated from her friends and relatives. The ostracizing of an unmarried pregnant girl extends to her family, especially her parents, who are seen as people who have not reared their daughter properly. The girl may try to hide her pregnancy from her parents and avoid going to a health clinic to consult about her pregnancy. In desperation, she might go to a traditional healer for an induced abortion that may cause her death. Her partner in the pregnancy experiences no stigma and is not ostracized. The girl's extended family and friends and even the government leave her on her own without support.

This situation contrasts sharply with the international reproductive health messages that were promoted at the International Conference on Population and Develop-

Table 1 Percentage of survey respondents, by their attitudes toward and knowledge of premarital pregnancy, according to age, sex, and religion, Jakarta, 1995

\begin{tabular}{|c|c|c|c|c|c|c|}
\hline \multirow[b]{3}{*}{ Question } & \multirow{2}{*}{\multicolumn{2}{|c|}{ Age }} & \multirow{2}{*}{\multicolumn{2}{|c|}{ Sex }} & \multicolumn{2}{|c|}{ Religion } \\
\hline & & & & & \multirow[b]{2}{*}{ Muslim } & \multirow{2}{*}{$\begin{array}{r}\text { Non- } \\
\text { Muslim }\end{array}$} \\
\hline & $15-19$ & $20-24$ & Male & Female & & \\
\hline \multicolumn{7}{|c|}{ What should a pregnant single woman do if she cannot marry the man who made her pregnant: } \\
\hline Continue her pregnancy & 77.6 & 73.9 & 73.6 & 78.9 & 78.1 & 69.1 \\
\hline Have an abortion & 1.9 & 3.2 & 2.6 & 2.1 & 2.4 & 2.1 \\
\hline Her decision & 20.5 & 22.9 & 23.8 & 18.9 & 19.6 & 28.7 \\
\hline \multicolumn{7}{|c|}{ Are you aware of any premarital pregnancy among your friends: } \\
\hline Yes; she had an abortion & 5.5 & 9.6 & 5.1 & 8.2 & 6.6 & 7.4 \\
\hline No & 71.2 & 22.3 & 55.3 & 57.1 & 56.8 & 54.3 \\
\hline \multicolumn{7}{|c|}{ Are you aware of any premarital pregnancy among your relatives: } \\
\hline Yes; she married the man and had the baby & 24.7 & $46.5^{\star \star}$ & 26.4 & $35.7^{\star}$ & 28.5 & $43.6^{*}$ \\
\hline Yes; she had an abortion & 0.6 & 0.0 & 0.0 & 0.7 & 0.5 & 0.0 \\
\hline No & 74.8 & 53.5 & 73.6 & 63.6 & 71.0 & 56.4 \\
\hline
\end{tabular}

${ }^{*}$ Difference significant at $<0.05 ;{ }^{* \star}<0.01$.

Note: Data are from the 1994-95 Jakarta Marriage Values and Sexuality Survey. The test for significant difference is based on chi-square 
ment (1994), the Fourth World Conference on Women (1995), and the 2005 World Summit and that were adopted by many international agencies and nongovernmental organizations (NGOs) that advocate for access to reproductive health information and services to all regardless of their sex, age, marital status, or sexual orientation (UN 1994 and 1995). Additional documents that have emphasized the importance of integrating sexual and reproductive health into the development agenda include the Delhi Declaration on Maternal and Child Health (2005) and the ICPD World Leaders Statement (2004). Reproductive rights are human rights, and the international community has articulated an individual's human right to plan her or his reproduction since 1968.

Although the Indonesian government is obligated to such international commitments, programs developed by the National Family Planning Coordinating Board (BKKBN), the Ministry of Health, the Ministry of Religion, the Ministry of Women's Empowerment, donor agencies working in Indonesia (Utomo 2003b), NGOs, the Indonesian Planned Parenthood Association (PKBI), and Yayasan Pelita Ilmu (Mepham 2001; Holzner and Oetomo 2004) are obliged to characterize premarital sex as unhealthy, abnormal, illegal, criminal, sinful, pathological, and even abusive when it involves same-sex relationships. These programs advocate strong sanctions against those involved in violating such prohibitions, and their messages are reinforced through intimidating messages concerning the dangers of sex outside marriage. Thus, although permissive sexual attitudes and behavior and recreational sex are increasing among young people, the government maintains highly conservative policies for dealing with unsafe and risky sexual behavior among young people who are single.

This official approach in Indonesia is compatible with the approach of the United States-based organization, Focus on the Family. This organization has developed an abstinence-only-until-marriage curriculum called "No apologies: the truth about life, love, and sex" (SIECUS Review 2005). The curriculum was originally written for schools in the United States but has also been marketed and used in Australia, Costa Rica, Japan, Singapore, South Africa, and Ukraine. The disadvantages of this curriculum are described in the SIECUS Review. The curriculum fails to take into account the cultural, social, and economic issues affecting the young; it instills fear and shame among young people, distorts information about STDs, disparages condom use, idealizes marriage, ignores gay and lesbian individuals, and relies on ineffective virginity pledges. Analyses have shown that that this curriculum does not reduce the prevalence of unintended pregnancy or sexually transmitted diseases, including HIV / AIDS (Bearman and Brückner 2001; Brückner and Bearman 2005).
Indonesia has been internationally recognized for its family planning program, which has succeeded in promoting contraceptive use and produced fertility decline. Since the implementation of the program in 1970, however, it has been directed exclusively toward married couples. The government began to implement a population education program curriculum nationally in the 1980s. The only objective of this program was to institutionalize the small, happy, and prosperous family norm, and the information provided was heavily weighted toward family planning rather than other reproductive health matters. In 1997, the government commenced a schoolbased program about HIV / AIDS, but the program was not formally incorporated into the school curriculum. Schools invite experts to talk about HIV / AIDS, and the program promotes the development of a peer-education school-based policy. Because these efforts are not incorporated into the curriculum, the talks and peer education are not standardized or provided uniformly in schools throughout the country.

A study by Smith and colleagues (2001) revealed that in Indonesia, the focus of sexual-health education is on the biology of sexual reproduction and not on sexual practices. Sexual activity is sanctioned only between husband and wife, and sex outside of marriage is strongly discouraged. Where sex-related topics are taught in elementary schools, they concern reproduction, the differences in male and female anatomy, and the physical changes associated with puberty. Although sex-related education is framed as "science," a moral perspective is presented as well. In secondary schools, family planning methods are mentioned, and the advantages and disadvantages for the user are described. HIV is referred to as the AIDS virus but the information presented sometimes fails to differentiate between HIV and AIDS. The ABCs of preventing sexual transmission of HIV are not taught, but they are sometimes delivered by NGO representatives when they are invited to visit schools.

Donor agencies such as the Ford Foundation, UNAIDS, UNFPA, and the World Bank have funded adolescent reproductive health (ARH) trial and pilot projects in several provinces of Indonesia to be presented along with the existing activities and programs provided by NGOs (Hasmi 2002). In 1999, for the first time, a national focus on ARH was incorporated in the National Development Program (Propenas). This new focus was linked with the work of Khofifah Indarparawangsa, the Minister for Women's Empowerment and Head of the National Family Planning Coordinating Board, who was appointed by President Abdurahman Wahid. Although she came from a conservative, traditional, religious background, her ARH policy was liberal. She established an Adolescent and Reproductive Rights Protection Directorate 
within the National Family Planning Coordinating Board (BKKBN) and a similar division at the State Ministry of Women's Empowerment.

The Minister also made another major policy shift when she declared that pregnant students should be given a chance to finish their schooling, that they should not be expelled but be given a "break" from school during their pregnancy. Thereby, two goals could be achieved: the pregnant student would be given an opportunity to proceed with her education and career development, and the incidence of premarital induced abortion would be reduced. Many people rejected this policy shift on the grounds that it would encourage more students to become pregnant. In response, the Minister argued that people would be better off if they took preventive rather than curative steps. She also pointed out that emergency contraceptives should be given to those girls who have previously undergone premarital abortion (Kompas 2000). This policy leap was a brave one because, up to that point, open discussion of these issues was taboo among government officials. Toward the end of 1999, policymakers in the health and education departments were considering several potential strategies to emphasize the importance of providing reproductive health education in the school curricula (Media Indonesia Online 2000). Since then, however, political changes have halted this policy impetus in its tracks, and no action has been taken to improve the status quo.

\section{Legal Barriers to Providing Reproductive Health Information and Services to Adolescents}

Legal barriers have largely prevented the establishment of enlightened reproductive health policy to benefit Indonesian adolescents. These include Law No. 10/1992 on Population and Family Welfare currently under review for amendment, which restricts family planning services for single young people, and Health Law No. 23/1992, which defines abortion as illegal, although the public is generally aware that abortions are widely available from medical and nonmedical personnel. Because family planning and reproductive health services are not easily accessible to them and because induced abortion is illegal, single women often resort to unsafe abortion services.

Law No. 23/2002 on Child Protection also restricts the availability of reproductive health information and services. According to this law, children are defined as individuals younger than 18 , including fetuses. The prevention of a child's early marriage is a parental responsibility by law (Part IV, clause 26 para 1), yet the 1974 Marriage Law permits the marriage of 16-year-old girls. Part II on Health, clause 46 of Law No. 23/2002, states that the government and parents have joint responsibility to ensure that children be protected from sicknesses that may be life threatening or cause disability. This clause could be used to promote the availability of reproductive health information and services for adolescents, but if this course were taken, a conflict would ensue with the Health Law concerning abortion and the Law on Population and Family Welfare described above. Part III on Education, clause 48, states that the government is obligated to provide a minimum of nine years of education for children, but does not mention reproductive health and sexuality education.

The likelihood that the Indonesian government will establish laws to promote reproductive health education and services is significantly hindered by the recent development of regional syariah laws. Since the decentralization law in 2001 was passed, whereby local governments were authorized to regulate their own districts, local regulations implementing syariah law have taken effect, especially in Aceh, Batam, Bengkulu, East Java-Madura, Gorontalo, Palembang, Riau, South Sulawesi, West Java, West Nusa Tenggara, and West Sumatra. To date, 54 regions have implemented syariah regulations, and more are expected to pass (Utomo 2006b). Penalties for violating such regulations vary; the most severe include public whipping and imprisonment. For example, in $\mathrm{Bu}$ lukumba (a village in South Sulawesi), Village Regulation No. 5/2006 states that whipping is the penalty for those involved in adultery (100 lashes for a single man or woman, 80 lashes for a person who accuses someone of having a sexual affair without being able to provide four witnesses); 40 lashes is the penalty for gambling; 40 lashes for those selling alcoholic drinks and 40 lashes for the person drinking; and for assault, the number of lashes depends upon the number of physical strikes the assailant gave the victim. A bamboo stick is used for the whip, and the whipping is performed publicly in front of the village head's house. Since the local syariah regulations have been implemented in Bulukumba, criminal offenses have decreased substantially (Gatra 2006; Tempo 2006). Regional regulations inspired by syariah law may also violate national legislation, for example, Law No. 32/2004 on Regional Governance, which states that religion is not under the jurisdiction of a regional authority (Gatra 2006). The sex-religion combination is an explosive mix in Indonesia, preventing sensible discussion of government programs for young people.

In contrast to the government's inaction concerning reproductive health programs for young people, programs and laws concerning gender empowerment (aside from the regional syariah regulations) have been developing rapidly since 1998 - the beginning of the Reform Era. Progressive development on this front can be observed in 
the intense public discussion of violence against women, domestic violence, trafficking of women and children, gender mainstreaming, women's empowerment, and planning budgets for development programs that are sensitive to gender issues. Media coverage of cases of domestic violence, legal procedures for sexual assault within marriage, and unjust treatment of female migrant workers abroad has been extraordinary compared with the coverage of such issues a decade ago, before the fall of Suharto. In a recent development, Law No. 23/2004 on the Abolition of Domestic Violence has proved its effectiveness. Since it was implemented, NGOs working on women's legal issues have reported an increase in reporting and filing of cases of domestic violence (Pambudy and Hartiningsih 2006). According to this law, the family is defined as including residential domestic staff, ${ }^{4}$ and domestic violence includes physical, sexual, and psychological abuse and neglect. With the passage of this law, the Indonesian government criminalized marital rape for the first time (Asia Foundation et al. 2006).

If programs, policies, and laws are working in favor of gender equity and women's empowerment in Indonesia at a time when fundamentalist Islamic movements are on the rise, we must ask why policies and laws concerning the availability of reproductive health information and services for single young people are absent from the political agenda. The answer may lie in the power and status that adult women have obtained in Indonesia today. All but the most fundamentalist of Muslims find it difficult to argue that violence perpetrated by husbands upon their wives is acceptable behavior. Thus, the majority moderate Islamic viewpoint is able to prevail, informed by Western and international perspectives and strategies. But the reforms that have been enacted have been for the protection of adult females, primarily. Adolescent girls are considered to have few rights of their own and, especially, no right to engage in sex, which is defined as an adult activity. Even young people who are effectively adults - that is, of voting age- - have no right to engage in sexual activity so long as they are not married. Therefore, arguing for reform in this area is difficult, although the consequences to health and life of nonintervention are as severe as they are in cases of domestic violence. Indeed, the empowerment of adult women must be based on the rights of females who are not yet adults.

\section{Conclusion}

The rise of fundamentalist Islamic forces during the Reform Era of the past decade has reversed the progress that might have been made toward a détente between Western ideas and traditional Indonesian Islamic idealized moral- ity with regard to adolescent reproductive health. Proponents of the fundamentalist perspective employ distorted images of Western-style sexuality to attack Western influence. For a government trying to balance many competing forces, including regional separatist movements, sexuality has become a topic that is best avoided. In the context of HIV / AIDS, however, sexuality cannot be ignored completely. The danger from the spread of HIV / AIDS is evident to the government. Pressure is being brought to bear upon the government from international agencies such as UNAIDS and the World Health Organization to deal with the challenge inherent in the HIV / AIDS pandemic. The government, however, chooses to focus upon the "abstinence" and "be faithful" components of the ABC policy framework, and not the C-condom use.

The impact of traditional practices on girls' health has been addressed by the introduction of severe sanctions for medical practitioners who perform female circumcision. At the same time, in matters relating to adolescents' sexuality and its concomitant risks to their health, the government has developed a blind spot. Furthermore, debating the issue in the current political climate is difficult. The government fears it as divisive, and so it remains absent from the political agenda. This impedes progress, but possibilities for action remain.

Almost three decades ago, the government established years of basic compulsory education as compulsory for all (Law No. 2/ 1979). The government could take a significant step by establishing a new regulation (Peraturan Pemerintah) attached to this law underlining the importance of including reproductive health education during these years of compulsory schooling. Such a regulation should promote both ARH education and provide an introduction to gender issues and women's empowerment to counteract sexual behaviors that persist as a result of inadequate understanding of sexuality and reproductive health. Sexual double standards, attitudes relating to the importance of women's virginity at marriage, sexual harassment, and sexual assault continue as a result of a profound gender gap that begins well before adulthood. Reproductive health education should be included in school curricula so that the students of the next generation will understand the risks and consequences of unsafe sex, unsafe abortion, sexual harassment and assault, and drug-related behavior. If the government were to introduce gender and women's empowerment issues into the school curriculum and combine them with reproductive health education, young Indonesians would learn that in matters of sexuality and reproductive health, men and women bear equal responsibility, and the attitude that reproductive health, family planning, childbearing, childrearing, and caring for family health are solely the responsibility of women would be less prevalent. 
The authors have begun a study of the existing school curriculum, textbooks, and teaching for years 1 through 12 , in association with Indonesian social science researchers. The objective of this study is to encourage the government to begin curriculum reform in reproductive health and gender education. In the current political climate, progress in this area can be made only through the development of education programs that are acceptable to mainstream Muslim educators and opinion leaders. Designing such programs is only the first step toward implementation. The new programs must be acceptable to the Indonesian government, and the material must be incorporated into textbooks to be used across the country. Popular media and youth-related NGOs are other potential avenues for change. Approaches consistent with new curriculum materials could be developed for the media and for use by NGOs. Finally, these new materials could engage parents to take part in their children's education.

\section{Notes}

1 For the purposes of this study, young people are defined as those aged 15-24 and still single. This group is unreached by the government's reproductive and family planning services, which are provided only to married people.

2 The Indonesian Population and Family Welfare Law no. 1992 states that the family planning program and services are intended only for married couples (Xenos 1990; Dahlan et al.1992).

3 In 1997, US $\$ 1=$ Rp. 2,363; in 2007, US $\$ 1=$ Rp. 8,993.

4 Families in urban and, to some extent, in rural areas commonly have live-in housekeepers. Middle- and upper-class families often employ a babysitter and a driver.

\section{References}

Arian, Cut Hs. 1982. Perkawinan dan perceraian pada masyarakat Aceh. [Marriage and divorce among the Acehnese community.] Yogyakarta, Indonesia: University of Gadjah Mada Population Study Center.

The Asia Foundation, Asian Development Bank, Canadian International Development Agency, National Democratic Institute, and the World Bank. 2006. Indonesia Country Gender Assessment. Manila: Southeast Asia Regional Department, Regional and Sustainable Development Department, Asian Development Bank.

Bearman, Peter and Hannah Brückner. 2001. "Promising the future: Virginity pledges and the transition to first intercourse." American Journal of Sociology 106(4): 859-912.

Brückner, Hannah and Peter Bearman. 2005. "After the promise: The STD consequences of adolescent virginity pledges." Journal of Adolescent Health 36(4): 271-278.

Cendrawasih Pos. 2006. “Di Biak, 51 IRT Dilaporkan Kena AIDS” (In Biak, 51 housewives reported with AIDS). <http:/ / www.cendrawasihpos.com/utama/h.2.html.> Accessed 7 August 2006.

Central Bureau of Statistics (CBS) [BPS-Statistics Indonesia]. 2003. “Brief analysis of the 2000 Population Census." <http: / / www.bps.go.id/ sector/population/pop2000.htm>. Accessed 10 October 2007.
Central Bureau of Statistics (CBS) [BPS-Statistics Indonesia] and ORC Macro. 2004. Indonesian Young Adult Reproductive Health Survey 2002-2003. Jakarta and Calverton, MD: CBS and ORC Macro.

Dahlan, Alwi., S. Sinarsari Ecip, Inar Ichsana Ishak, et al. 1992. Kelembagaan Kependudukan (Population Institution). Jakarta: State Ministry of Population and Environment.

Djaelani, Joice. 1995. "AIDS dan pemberdayaan wanita." ["AIDS and women's empowerment."] Prisma No. 3: 39-43.

Ford, K., P. Fajans, and D.N. Wirawan. 1993. "AIDS knowledge, condom attitudes, and sexual behavior among male sex workers and male tourist clients in Bali, Indonesia." Health Transition Review 3(2): 191-203.

Gatra. 1996. Advertisement about Global Jaya School, PT Era Media Informasi (Era media information) 2(29).

—. 2006. "Menguji niat baik perda." ["Testing the good will of regional regulations."] 6 (May): 25-26.

Geertz, Hildred. 1961. The Javanese Family: A Study of Kinship and Socialization. New York: The Free Press of Glencoe.

Grace, J. 1996. “Kurang pendidikan (lacking education): Marriage, divorce and polygamy in Sasak Village, East Lombok, Indonesia." Paper presented at the Biennial Asian Studies Association of Australia Conference, La Trobe University, Melbourne, Australia, 8-11 July.

Gunawan, S. 1995. "AIDS dan kesejahteraan social." ["AIDS and social welfare."] Prisma No. 3: 39-43.

Hanum, S.H. 1996. "Kasus "kumpul" sebelum kawin: trend dan karakteristik individu." ["Cases of consummation before marriage: trends and characteristics of respondents."] Populasi No. 7: 15-24.

Hasmi, Eddy Nurul. 2001. "A note on adolescent reproductive health policies in Indonesia." Paper presented at the International Conference on Asian Youth at Risk: Social, Health, and Policy Challenges, Taipei, 26-29 November.

- "Meeting reproductive health needs of adolescent in Indonesia." <http://www.bkkbn.go.id/hqweb/ceria/index.html>. Accessed 10 September 2007.

Holzner, Brigitte M. and Dédé Oetomo. 2004. "Youth, sexuality and sex education messages in Indonesia: Issues of desire and control." Reproductive Health Matters 12(23): 40-49.

Hull, Terence H. 2002. "The marriage revolution in Indonesia." Paper presented at the Annual Meeting of the Population Association of America, Atlanta, 9-11 May.

Hull, Terence H., Endang Sulistyaningsih, and Gavin W. Jones. 1997. Pelacuran di Indonesia Sejarah dan Perkembangan. [Prostitution in Indonesia: History and development.] Jakarta: Pustaka Sinar Harapan.

Hull, Terrence H., Sarlito W. Sarwono, and Ninuk Widyantoro. 1993. "Induced abortion in Indonesia." Studies in Family Planning 24(4): 241-251.

Hull, Valerie J. 1975. "Fertility, socioeconomic status, and the position of women in a Javanese village." Doctoral dissertation, The Australian National University.

Iskandar, N. 1970. Some Monographic Studies on the Population in Indonesia. Jakarta: University of Indonesia Demography Institute, Faculty of Economics.

Janssen, P.L., G. Petersen, and V. Darmawi. 2008. UNAIDS Second Independent Evaluation 2002-2008. Country Visit to Indonesia Summary Report. Geneva: UNAIDS

Jennaway, Megan. 2008. “Cowboys, cowoks, beachboys and bombs: Matching identity to changing socioeconomic realities in post-2005 North Bali." The Asia Pacific Journal of Anthropology 9(1): 47-65.

Jones, Gavin W. 1994. Marriage and Divorce in Islamic South-East Asia. New York: Oxford University Press. 
_. 2002. "The changing Indonesian household." In Women in Indonesia: Gender, Equity and Development. Eds. K. Robinson and S. Bessell. Singapore: Seng Lee Press. Pp. 219-234.

Kompas. 2000. "Khofifah Indar Parawangsa: Siswi Hamil Jangan Dikeluarkan dari Sekolah." ["Pregnant students should not be expelled from school."] 5 February.

. 2006a. "Pansus: RUU APP selesai Juni 2006" (Special committee draft APP Law finished June 2006).

2006b. "Free sex siswa Bogor gawet hasil penelitian doctor IPB." ["Free sex among students in Bogor is critical result of a PhD study."] http:// www.kompas.com/kirim_berita/print.cfm?nnum= 96635>. Accessed 18 May 2006.

Kurniawan, K. Ukik. 2000. "Revolution of decision making among young women aged 15-24 in Indonesia: A review of demographic data 1971-1997." Unpublished MA research project. The Australian National University Research School of Social Sciences.

Linnan, M., Kestari, and M. Kambodji. 1995. Adult Sexual Behavior and Other Risk Behavior in East Java. Jakarta: Yayasan Prospektif.

Malhotra, Anju. 1991. "Gender and changing generational relations: Spouse choice in Indonesia." Demography 28(4): 549-570.

McDevitt, Thomas M., Arjun Adlakha, Timothy B. Fowler, and Vera Harris-Bourne. 1996. Trends in Adolescent Fertility and Contraceptive Use in the Developing World. US Bureau of the Census, Report IPC /51. Washington, DC: United States Government Printing Office.

McDonald, Peter. 1984. Changing Courting Behaviour among Indonesian Youth: National Image versus Local Custom. Canberra: the Australian National University.

—. 1994. "Families in developing countries: Idealized morality and theories of family change." In Tradition and Change in the Asian Family. Eds. L.J. Cho and M. Yada. Honolulu: East-West Center and Tokyo: Nihon University Research Center. Pp. 19-27.

. 1995. "Syncretism: Islam and Malay family organization." In The Australian National University Reporter 5 (28 June).

McDonald, Peter and Edenf Abdurahman. 1974. "Marriage and divorce in West Java: An example of the effective use of marital histories." Jakarta: University of Indonesia Demographic Institute, Faculty of Economics.

Media Indonesia Online. 2000. “Dikhawatirkan lecehkan lembaga perkawinan pelajar hamil boleh sekolah." ["It would be an alarming threat to marriage institutions if pregnant students were allowed to go to school."] Jakarta: Media Indonesia-Kesra 7 February.

2006a. "Seorang Balita di Banyumas meninggal akibat AIDS." ["One under-five died in Banyumas because of AIDS."] 9 July. <http: / / www.mediaindo.co.id / newsprint.asp?Id=105449\&Jenis $=$ a\&cat_name $=$ Kesehatan $>$. Accessed 10 July 2006.

. 2006b. "Seorang penderita AIDS meninggal di Padang." ["AIDS case died in Padang."] 8 July. <http://www.mediaindo.co.id/ newsprint.asp? $\mathrm{Id}=105377 \&$ Jenis $=$ a\&cat_name $=$ Kesehata $>$. Accessed 10 July 2006.

. 2006c. "Fenomena gunung itu bernama aborsi." ["The mountain phenomenon is called abortion."] 8 July. <http: / / www.mediaindo. co.id / newsprint.asp?Id=105377\&Jenis=a\&cat_name=Kesehatan $>$. Accessed 10 July 2006.

Mepham, I. 2001. Final Report of NGO Adolescent Reproductive Health Programs in Indonesia. Unpublished STARH Project report. Jakarta: National Family Planning Coordinating Board.

Muhaimin, T., A. Adisasmita, L. Sabri., et al. 1993. "Study to identify knowledge, attitudes and behaviour about delayed menstruation, as well as variables affecting attitude toward access to comprehen- sive reproductive health services for low income women in Jakarta and Bogor 1992." Report. Jakarta: Reproductive Health Study Group, University of Indonesia School of Public Health.

Muliakusuma, Sutarsih. 1982. "Perkawinan dan perceraian pada masyarakat Betawi: Suatu studi kasus di Desa Balekambang, Jakarta." ["Marriage and divorce among the Betawi community: A case study in Balekambang Village, Jakarta."] Yogyakarta, Indonesia: University of Gadjah Mada Population Study Center.

Muninjaya, A.A.G. 1993. "Needs assessment reproduksi sehat remaja di Kota Madya Denpasar, 1993." ["Needs assessment of reproductive health among adolescent in Denpasar, 1993."] Report. Jakarta: Yayasan Kusuma Buana and State Ministry of Population.

Pambudy, N. and H. Hartiningsih. 2006. "Masih banyak persoalan, tetapi ada perbaikan situasi." ["Many problems exist but there are improvements in the situation."] Kompas, 14 January.

Parini and Mudjajadi. 1995. "Pendidikan kesehatan reproduksi dalam keluarga, suatu studi awal di Daerah Istimewa Yogyakarta." ["Reproductive health education in the family, a preliminary study in Daerah Istimewa Yogyakarta."] Yogyakarta, Indonesia: University of Gadjah Mada Population Studies Center.

Planned Parenthood Federation of America (PPFA). 2005. "Realitybased education and learning for life: What you should know about sexuality education." New York: PPFA.

Private Agencies Collaborating Together (PACT). 1994. Direktori (19931994), Organisasi yang bergerak dalam bidang penanggulangan HIVI AIDS di Indonesia. [Directory [1993-1994] Organization Specializing in HIV/AIDS Prevention in Indonesia.] Jakarta: PACT.

Purdy, Christopher H. 2006. "Fruity, fun and safe: Creating a youth condom brand in Indonesia." Reproductive Health Matters 14(28): 127-134.

Purwanto, Toto and Harmudya. 1992. "Validitas penelitian perilaku seks remaja." ["Validity of the study of premarital sex among young people."] Bengkulu: Harian Semarak. P. 4.

Putra, A.R., Eka M. Baharudin, Djayadilaga, et al. 1984-85. Corak remaja pada program remaja sehat di klinik Raden Saleh Jakarta. [Characteristics of adolescents in the healthy adolescents program in the Clinic of Raden Saleh, Jakarta.] Jakarta: Dr. Cipto Mangunkusumo Hospital and University of Indonesia.

Rajab, Budi. 2006. "Seksualitas dan peran media." ["Sexuality and the role of the media."] Kompas, 14 July. <http: / / www.kompas.com>. Accessed 10 October 2006.

Sadli, Saparinah and Biran Affandi. 1976. "Sikap keserba bolehan dalam hubungan antar jenis." ["Permissiveness on mixing between the sexes."] Prisma.

Sarwono, Sarlito Wirawan. 1981a. "Perilaku seks pada remaja dalam beberapa penelitian." ["Teenagers' sexual behaviour from various studies."] Tempo 19 September.

_ 1981b. Pergeseran Norma Perilaku Seksual Kaum Remaja. [Changes in sexual behavior norms among adolescents.] Jakarta: CV. Rajawali and the Indonesian Planned Parenthood Association.

SIECUS Review. 2005. "Summary: No apologies: The truth about life, love and sex." <http: / / www.secus.org/index.cfm?fuseaction=Page. viewPage\&pageId=639\&grandparentID $=4772$ parentID $=633>$. Accessed 10 October 2006.

Sinar. 1997. "Ini bisnis Rp 18 Triliun, Bung!" ["This is a 18 trillion rupiahs businessman!") Sinar 26 July: 60.

Singarimbun, Masri. 1987. "Perkawinan pada masyarakat Jawa." [“Marriage among the Javanese."] Paper presented at Population Seminar on Marriage Pattern in Several Areas of West Java. University of Padjadjaran Population Studies Center, Bandung, Indonesia, 18 July. 
1991. "Norma-norma dan perilaku seks remaja." ["Norms and sexual behavior among young people."] Populasi No. 2: 11-23.

Situmorang, Agustina. 2001. "Adolescent reproductive health and premarital sex in Medan." Doctoral thesis, The Australian National University Division of Demography and Sociology, Research School of Social Sciences. Unpublished.

Smith, G., S. Kippax, and P. Aggleton 2001. "HIV and sexual health education in primary and secondary schools: Findings from selected Asia-Pacific countries October 2000." Report. National Centre in HIV Social Research, Faculty of Arts and Social Sciences. Sydney: The University of New South Wales.

Soeradji, M. Budi. 1979. "Marriage and divorce in Indonesia: A demographic study." Doctoral thesis, University of Chicago.

Soeradji, M. Budi and Sri Harijati Hatmadji. 1982. "Perbedaan umur perkawinan antar daerah." ["Differences in age at marriage among regions."] Jakarta: University of Indonesia Demographic Institute.

State Ministry of Population and Environment and Population Study Centre, University of Gadjah Mada. 1991-92. “Determinan pengetahuan, sikap dan praktik kesehatan reproduksi remaja di Kota Manado." ["Adolescent reproductive health determinants of knowledge, attitudes, and behavior in Manado."] Yogyakarta, Indonesia: University of Gadjah Mada.

The Straits Times. 2000. "Abortion reaches 'alarming' level in Indonesia." 26 October. <http:/ / www.hartford-hwp.com/archives/54b/075. html $>$. Accessed 18 September 2006.

Sudewa, A. 1980. "Pengaruh pemilihan jodoh, umur perkawinan dan perceraian terhadap fertilitas: kasus Ngalik." ["Effect of choosing marriage partner, age at marriage and divorce on fertility: a case study of Ngalik."] Yogyakarta, Indonesia: University of Gadjah Mada Population Studies Center.

Tempo. 2006. "Pecut bambu dari Bulukumba." [“Bamboo whip from Bulukumba."] Tempo 14 May: 33.

Tiara. 1994. "Pendidikan sex untuk anak, perlu!" ["Sex education for children is a must!"] Tiara 14 August: 46-47.

Tiwon, Sylvia. 1996. "Models and maniac, articulating the female in Indonesia." In Fantasizing the Feminine in Indonesia. Ed. L.J. Sears. Durham, NC: Duke University Press. Pp. 47-70.

UNAIDS. 2002.<http: / / www.unaids.org>. Accessed 10 October 2006. . 2006. Country reports at <http: / / www.unaids.org >. Accessed 25 September 2006.

United Nations (UN). 1994. Population and Development: Programme of Action Adopted at the International Conference on Population and Development, Cairo, 5-13 September. <http:/ / www.un.org/popin/icpd/ conference/ offeng/poa.html>. Accessed 20 April 2009.

1995. The Fourth World Conference on Women, Beijing, China. <http: / / www.jgc.org/Beijing/ un>. Accessed 25 September 2006.

Utomo, Budi, Nick G. Dharmaputra, Budi Haryanto, Djoko Hartono, and Richard Makalew. 1997a. Indonesia HIV/AIDS Behavioural Surveillance Survey: Results from the cities of North Jakarta, Surabaya, and Manado. Depok, Indonesia: University of Indonesia Centre for Health Research.

Utomo, Budi, Vera Hakim, Atas H. Habsyah, et al. 2000. “Study report incidence and social-psychological aspects of abortion in Indonesia: A community-based survey in 10 major cities and 6 districts." Depok, Indonesia: University of Indonesia Centre for Health Research.

Utomo, Budi, A. Irwanto, and A. Manaf. 1997b. "STD/HIV trends and behavior changes in Indonesia." Paper presented at the Workshop on Evidence of Behavioural Change in the Context of HIV Decline. Bangkok, 19-22 May 1997.

Utomo, Budi, Heru Suparno, F.P. Siagian, Nick G. Dharmaputra, Vera Hakim, and A. Ismail. 2001. "Behavioral surveillance survey among injecting drug users in Jakarta, 2000." Centre for Health University of Indonesia.

Utomo, Iwu D. 1995. "Government concerns, awareness and AIDS movement: Indonesian perspective." In Indonesia dalam Transisi Tantangan dan Perubahan Setelah 50 Tahun Merdeka. [Indonesia in Transition, Challenges after 50 Years of Independence.] Ed. G.H. Sofyan. Jakarta: Halmahera Foundation [Foundation for Indonesia-Australia Society]. Pp. 238-254.

. 1997. "Sexual attitudes and behaviour of middle-class young people in Jakarta." Doctoral thesis, Department of Demography, Research School of Social Sciences, The Australian National University, Canberra.

2003a. "Reproductive health education in Indonesia: School versus parents' roles in providing sexuality information." RIMA (Review of Indonesian and Malaysian Affairs Journal) 37(1): 107-134.

. 2003b. "Adolescent reproductive health in Indonesia: Status, policies, programs, and issues." Washington, DC: POLICY Project.

. 2006a. "Maraknya bisnis perawatan organ intim perempuan: kommersialisasi mitos seks peret." ["The booming industries of vagina treatments: commercialization of the myth on tight sex."] Journal Perempuan Online 15 August. <http: / / www.jurnalperempuan. com/yjp.jpo/ ?act=feature percent7C-22 percent7CX>.

. 2006b. "Women's rights and regional regulations in provincial Indonesia." The Australian National University Development Network. Development Bulletin No. 71: 97-99.

Utomo, Iwu D. and Terence H. Hull. 2006. "Vaginal practices in Indonesia. Making the connection: Sexuality and reproductive health." News and Views on Sexuality: Education, Health and Rights, Sexuality Information and Education Council of the United States 4(3). <http: / / www.siecus.org/inter/connection/conn0059.html\#5>. Accessed 10 October 2007.

Van Der Sterren, A., Alison Murray, and Terry Hull. 1997. “A history of sexually transmitted diseases in the Indonesian Archipelago since 1811." In Sex, Disease, and Society. Eds. Milto Lewis, Scott Bamber, and M. Waugh. Westport, CT: Greenwood Press. Pp. 203-229.

Widyantoro, Ninuk. 1996. "Learning about sexuality through family planning counselling sessions in Indonesia." In Learning About Sexuality A Practical Beginning. Eds. Sondra Zeidenstein and Kirsten Moore. New York: Population Council and International Women's Health Coalition. Pp. 158-170

- 1992. Kehamilan Yang tidak diinginkan sebuah tinjauan psikologis. [Unwanted pregnancy from a psychological perspective.] Medan: North Sumatra Indonesian Planned Parenthood Federation.

Widyantoro, N. and H. Lestari. 2004. Laporan Penelitian Penghentian Kehamilan Tak Diinginkan yang Aman Berbasis Konseling Penelitian di 9 Kota Besar. [Counseling-Based Safe Termination of Unwanted Pregnancies in Nine Cities]. Report. Jakarta: Women's Health Foundation.

Xenos, Peter. 1990. "Youth, Sexuality and Public Policy in Asia: A Research Perspective." Reprints of the East-West Population Institute No. 236. East-West Center, Honolulu: University of Hawaii.

Yatim, D.I. 1995. "Strategi komunikasi mengenai Aids di Indonesia." ["AIDS communication strategies in Indonesia."] Prisma No. 3: 39-43. 